\title{
Evaluation of $\beta$-galactosidase activity of commercial probiotic supplements available in the local market in Greensboro, North Carolina market
}

\begin{abstract}
The objective of this study was to evaluate the $\beta$-galactosidase activity of commercial probiotic supplements available in the market. Fifteen different supplements (15) were included in the study. Two capsules of each supplement were transferred into $10 \mathrm{ml}$ fresh, sterile MRS broth and incubated at $37^{\circ} \mathrm{C}$ for $10-12 \mathrm{~h}$ to allow bacterial cells to recover from any environmental stressors. Aliquots from each supplement $(100 \mu 1)$ were then inoculated into batches of $10 \mathrm{ml} \mathrm{TPY}$ broth with lactose (induced) or glucose (un-induced) and incubated for $14 \mathrm{hr}$. at $37^{\circ} \mathrm{C}$. After bacterial growth reached the mid $\log$ phase (optical density $0.7-0.9 ; 610 \mathrm{~nm}$ ), the $\beta$-gal activity was determined using o-nitrophenyl- $\beta$-D-galactoside (ONPG) as a substrate. The activity of $\beta$-gal in the uninduced group ranged between 0 and 600Millerunits, whereas activity in the induced group ranged from 0 to 1300 Millerunits. These findings indicate that $\beta$-gal activity in the tested supplements varies. This would mean that commercially available probiotic supplements exhibit different degrees of activity, and consumers should be aware of this variability when choosing probiotic supplements that purportedly confer health benefits.
\end{abstract}

Volume I Issue 3 - 2015

\author{
Desarae N Johnson,' Sulaiman O Aljaloud, ${ }^{2}$ \\ Rabin Gyawali,' Salam A Ibrahim' \\ 'Food and Nutritional Sciences, North Carolina Agricultural \& \\ Technical State University, USA \\ ${ }^{2}$ Department of Exercise Physiology, King Saud University, Saudi \\ Arabia
}

Correspondence: Salam A Ibrahim, Food Microbiology and Biotechnology Laboratory, Food and Nutritional Sciences, I7I Carver Hall, North Carolina Agricultural \& Technical State University, Greensboro, NC 274I I-I064, USA, Tel 336-285-4860 (O), Fax 336-334-7239, Email ibrah00I@ncat.edu

Received: June 17,20I5 | Published: October 15, 2015

Keywords: probiotic supplements, $\beta$-Galactosidase ( $\beta$-Gal), lactose intolerance

\section{Introduction}

In the early $20^{\text {th }}$ century, Eli Metchnikoff made the first observation of the positive role microorganisms play in human health and longevity. While studying rural populations in Europe, Metchnikoff noticed that that people consuming diets consisting largely of milk fermented by lactic acid bacteria were living longer lives. ${ }^{1-4}$ Officially named "probiotics" in 1953, these microorganisms were a group of bacterial strains found to positively enhance the function of the digestive tract. ${ }^{3,4}$ Later, in 2002, the Food and Agriculture Organization (FAO) defined probiotics as "Live microorganisms administered in adequate amounts that confer a beneficial health effect on the host."

The health conferring microorganisms of probiotics are commercially available to consumers in many forms including probiotic supplements (capsules, gummies, liquids, powders, and tablets) and consumer interest in probiotics has risen in the last 20 years ${ }^{3,4}$ and probiotics supplements become more popular despite the predominance of probiotic food products that are available on the market. They comprise approximately $65 \%$ of the world functional food market. Probiotic products are foods, which improve intestinal microflora and support good health of the consumer. The live bacteria present in the probiotic products are lactic acid bacteria, including Lacto bacilli, and bifidobacteria. Apart from health claims and maintenance of intestinal microflora, they protect against infections, reduce blood cholesterol levels and stimulate the immune system. Probiotics can also alleviate lactose intolerance due to the ability to produce lactase ( $\beta$-galactosidase) which hydrolyses lactose to glucose and galactose in order to be absorbed in the small intestine. ${ }^{5,6}$
The prevalence of lactose intolerance varies from population to population. In the U.S., $80 \%$ of Asian and Native Americans, $75 \%$ of African Americans, $51 \%$ of Hispanic Americans, and $21 \%$ of Caucasian Americans are lactose intolerant. ${ }^{7}$ These individuals do not possess the lactase enzyme; thus, ingested lactose cannot be digested, in which case gut microbiota attack the lactose. Several studied have found that probiotics in the intestinal lumen have the ability to produce lactase, thereby relieving the symptoms of lactose intolerance. ${ }^{8}$ The enzyme activity of probiotic supplements is also of interest as a component of the viability of bacterial strains in the supplement. In terms of being considered for its potential use in alleviating symptoms of lactose intolerance, high $\beta$-gal activity is essential. To our knowledge, there have been only limited studies to address this issue. Therefore, the objective of this study was to evaluate the $\beta$-galactosidase activity of commercial probiotic supplements available in the local markets in Greensboro, North Carolina.

\section{Materials and methods}

\section{Sample preparation}

Two capsules of each probiotic supplement were added into individual tubes of fresh deMan, Rogosa \& Sharpe (MRS) broth and mixed for 15 to $30 \mathrm{~s}$ using a vortex. The samples were then incubated for $10-12 \mathrm{~h}$ at $37^{\circ} \mathrm{C}$ to allow for cell recovery and to evaluate the bacterial population and $\beta$-gal activity of each probiotic supplement.

\section{Bacterial population}

Each bacterial sample was serially diluted in $9 \mathrm{ml}$ of sterile $0.1 \%$ peptone water, after which appropriate dilutions $(100 \mu \mathrm{l})$ were 
transferred onto the respective agar in duplicate. Lactobacilli MRS agar (Difco, Detroit, MI, USA) plates were used for enumeration of Lactobacillus strains. Modified BIM-25 agar plates were used for the enumeration of bifidobacteria. ${ }^{9}$ Reinforced clostridium agar with bromocresol green and clindamycin (RCABC), was used for the enumeration of Lactobacillus acidophilus spp. Reinforced clostridium agar with aniline blue and dicloxacillin (RCAAD), which is differential for Bifido bacterium spp., was also used..$^{10}$ Plates were incubated for $72 \mathrm{~h}$ at $37^{\circ} \mathrm{C}$, and those containing $25-250$ colonies were counted to calculate bacterial populations.

\section{$\beta$-gal of Probiotic Supplements}

To determine the $\beta$-galactosidase activity, bacterial cells were collected at the middle of the exponential with optical density readings ranging between $0.75-0.95$ (O.D. $610 \mathrm{~nm}$ ). Cells were harvested by centrifugation of $6000 \mathrm{~g}$ at $4^{\circ} \mathrm{C}$ for $10 \mathrm{~min}$. using an Eppendorf 5415R centrifuge. Cells were washed twice with a $10 \mathrm{ml} \mathrm{Z}$ buffer (composed of $0.06 \mathrm{M} \mathrm{Na} \mathrm{HPO}_{4} ; 0.04 \mathrm{M} \mathrm{NaH} \mathrm{PO}_{4} ; 0.01 \mathrm{M} \mathrm{KCl} ; 0.001 \mathrm{M} \mathrm{MgSO}$. $\left.7 \mathrm{H}_{2} \mathrm{O}\right)$ and suspended in the same buffer. $10 \mu \mathrm{L}$ of chloroform was added to this bacterial suspension and mixed well. The mixture was then incubated at $37^{\circ} \mathrm{C}$ in a shaker with open caps for $30 \mathrm{~min}$. After incubation, $200 \mu 1$ of $\beta$-ONPG $(4 \mathrm{mg} / \mathrm{ml}$ in $0.1 \mathrm{M}$ phosphate buffer) were added to each tube and vortex in order to start the reaction. The reaction was stopped by adding $0.5 \mathrm{~mL}$ of $1 \mathrm{~N} \mathrm{Na}_{2} \mathrm{CO}_{3}$ after the expected yellow color had developed. The time taken for color to develop in each tube was recorded. Finally, the optical density was recorded at $\mathrm{OD}_{420}$ and $\mathrm{OD}_{550}$. Units of $\beta$-gal produced were calculated using the following equation:

$$
\text { Unit of } \beta-\text { gal }=\frac{1000\left(O D_{420}-1.75 * O D_{550}\right)}{t^{*} v * O D_{610 n m}}
$$

where $t$ represents time taken for color to develop and $\mathrm{v}$ represents the sample. $\beta$-gal units were calculated as described by Miller. ${ }^{11}$

\section{Results}

Table 1 shows the bacterial populations ( $\log \mathrm{CFU} / \mathrm{mL}$ ) found in commercial probiotic supplements tested in this study. The initial bacterial populations ranged from 3.87 to $9.50 \log \mathrm{CFU} / \mathrm{ml}$. Supplement 13exhibited the lowest number at $3.87 \pm 0.40 \log \mathrm{CFU} /$ $\mathrm{ml}$. Supplements 1, 25, and 15 exhibited the highest number with arrange of 9.12-9.50log CFU/ml. These results indicate that the bacterial population varied among the tested products. This variation could be a result of several factors including the bacterial strains, the added ingredients and processing conditions. Several studies in our laboratory have shown that added indigents during fermentation and processing could enhance the viability of probiotic supplements including calcium and proteins. ${ }^{9}{ }^{12-14}$ Figure 1 shows the $\beta$-gal activity of the fifteen commercial probiotic supplements both in the presence of glucose (uninduced) and lactose (induced). The activity of $\beta$-gal in the uninduced group ranged between 0 and 860 Millerunit $/ \mathrm{mL}$, and activity in the induced group ranged from 0to 1300 Millerunit $/ \mathrm{mL}$. Several supplements exhibited relatively high $\beta$-gal activity levels ranging from 800-1300Millerunits;

It is generally assumed that that high bacterial population of probiotics is an indication of high $\beta$-gal activity. Our results, however, demonstrate that a strong relationship between the probiotics population and enzyme activity is not always present. In the present study, seven supplements (\# 5, 6, 11-15) demonstrated a correlation between high population count and high induced enzyme activity. Three supplements (\# 1, 7and 9) showed a high population count with low activity; which could indicate that the cells did not produce high enzymatic activity. One supplement (\#8) was found to have a low population count and high enzyme activity. This could indicate that the cells were non-viable, but the enzyme was still present-ostensibly attributable to the heat resistant properties of $\beta$-gal and its capability of surviving the encapsulation process. One supplement (\#10) was found to have a low population count and low enzyme activity. Bacterial population and enzyme activity were classified as high or low based on previous work completed by Ibrahim and Carr in 2005 in which 500Millerunits or higher are considered high. ${ }^{10,14}$

Table I Bacterial populations in commercial probiotic supplements included in this study

\begin{tabular}{|c|c|c|}
\hline Supplement* & Bacterial strains & $\begin{array}{l}\text { Bacterial population } \\
\text { (Log CFU/ml) }\end{array}$ \\
\hline 1 & $\begin{array}{l}\text { Lactobacillus rhamnosus } \\
G G\end{array}$ & $9.39 \pm 0.00$ \\
\hline 2 & L. acidophilus & $9.12 \pm 0.02$ \\
\hline 3 & $\begin{array}{l}\text { L. acidophilus, B. bifidum, } L \text {. } \\
\text { bulgaricus }\end{array}$ & $8.54 \pm 0.00$ \\
\hline 4 & B. longum, B. lactis, B. breve & $7.76 \pm 0.08$ \\
\hline 5 & $\begin{array}{l}\text { L. rhamnosus, } L \text {. } \\
\text { acidophilus, L. reuteri }\end{array}$ & $9.20 \pm 0.00$ \\
\hline 6 & L. acidophilus & $8.61 \pm 0.00$ \\
\hline 7 & $\begin{array}{l}\text { L. acidophilus, } L \text {. } \\
\text { bulgaricus, } B \text {. bifidum, } B \text {. } \\
\text { longum, }\end{array}$ & $8.80 \pm 0.00$ \\
\hline 8 & B. longum & $5.39 \pm 0.00$ \\
\hline 9 & $\begin{array}{l}\text { L. gasseri, L. rhamnosus, } \\
\text { B. bifidum, B. longum, B. } \\
\text { infantis, B. breve, B. lactis }\end{array}$ & $8.44 \pm 0.30$ \\
\hline 10 & $\begin{array}{l}\text { L. plantarum, L. rhamnosus, } \\
\text { L. casei, L. acidophilus, } \\
\text { L. paracasei, B. lactis, B. } \\
\text { bifidum, B. breve, B. longum, } \\
\text { Bacillus subtilus }\end{array}$ & $5.86 \pm 0.2$ \\
\hline 11 & $\begin{array}{l}\text { B. breve, B. longum, } B \text {. } \\
\text { bifidum }\end{array}$ & $8.10 \pm 0.20$ \\
\hline 12 & B. animalis & $7.49 \pm 0.27$ \\
\hline 13 & B. lactis & $8.87 \pm 0.10$ \\
\hline 14 & $\begin{array}{l}\text { B. longum, B. lactis, } L . \\
\text { plantarum, L. rhamnosus }\end{array}$ & $6.67 \pm 0.09$ \\
\hline 15 & L. acidophilus & $9.50 \pm 0.30$ \\
\hline
\end{tabular}

*Each supplement was tested in duplicated at least 3 times. 


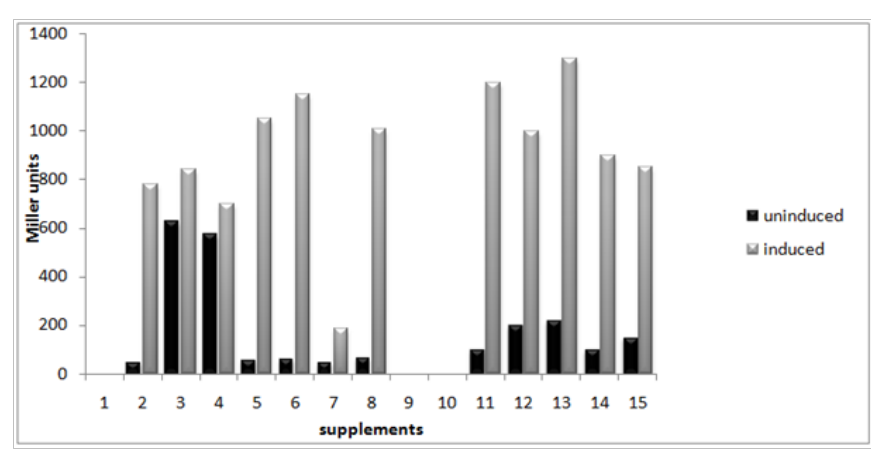

Figure I $\beta$-galactosidase activity in commercial probiotic supplements.

\section{Conclusion}

Our study revealed that bacterial populations among the tested products varied and did not match the actual label claims. We also found that $\beta$-gal activity may vary among these supplements. As a result, consumers could be taking supplements that may not confer the expected health benefits. Our research demonstrated that all probiotic supplements are not equal, specifically in terms of viability and enzyme activity. Therefore, in order to compensate for the variance in enzyme activity found in probiotic supplements, we would encourage consumers to maintain a balanced \& healthy diet that includes yogurt and other dairy products. Additionally, an important component of this diet should be functional foods as research has shown that functional foods can help enhance the growth and functionality of probiotics in the human microbiota.

\section{Acknowledgements}

This publication was made possible by grant number NC.X-2675-12-170-1 from the National Institute of Food and Agriculture and its contents are solely the responsibility of the authors and do not necessarily reflect the official view of the National Institute of Food and Agriculture.

\section{Conflict of interest}

The author declares no conflict of interest.

\section{References}

1. Bäckhed F, Ley RE, Sonnenburg JL, et al. Host-bacterial mutualism in the human intestine. Science. 2005;307(5717):1915-1920.

2. Biagi E, Nylund L, Candela M, et al. Through ageing, and beyond: gut microbiota and inflammatory status in seniors and centenarians. PloS one. 2010;5(5):e10667.

3. Tiihonen K, Ouwehand AC, Rautonen N. Human intestinal microbiota and healthy ageing. Ageing research reviews. 2010;9(2):107-116.

4. Song, Danfeng, Ibrahim, et al. Recent Application of Probiotics in Food and Agricultural Science. Probiotics. 2012.

5. Adams MR, Moss M. The Royal society of chemistry, Cambridge. Food Microbiology. 1999. p.181-186.

6. Sanders ME. Considerations for use of probiotic bacteria to modulate human health. J Nutr. 2000;130(2s supl):384S-390.

7. University of Georgia. Lactose Intolerance; 2015.

8. Tuohy Kieran M, Probert Hollie M, Smejkal Chris W, et al. Using probiotics and prebiotics to improve gut health. Drug discovery today. 2003;8(15):692-700

9. Darukaradhya, J, Phillips M, Kailasapathy K. Selective enumeration of Lactobacillus acidophilus Bifidobacterium spp., starter lactic acid bacteria and non-starter lactic acid bacteria from Cheddar cheese. International dairy journal. 2006;16(5):439-445.

10. Ibrahim SA, O'Sullivan DJ. Use of Chemical Mutagenesis for the Isolation of Food Grade $\beta$-Galactosidase Overproducing Mutants of Bifidobacteria, Lactobacilli and Streptococcus thermophilus. J Dairy Sci. 2000;83(5):923930 .

11. Shahbazi A, Mims MR, Li Y, et al. Lactic acid production from cheese whey by immobilized bacteria. Applied biochemistry and biotechnology. 2005;122 (1-3):529-540.

12. Alazzeh AY, Ibrahim SA, Song D, et al. Induction of $\alpha$-and $\beta$-Galactosidases in Lactobacillus reuteri using different protein and carbon sources. Food chemistry. 2009;117:654-659.

13. Ibrahim SA, Carr JP. Viability of bifidobacteria in commercial yogurt products in North Carolina during refrigerated storage. International journal of dairy technology. 2006;59(4):272-277.

14. Ibrahim SA, Rabin G. Lactose Intolerance. Milk and Dairy Products in Human Nutrition: Production, Composition and Health; 2013. p. 246-260. 